\title{
PERAN MASYARAKAT SEKITAR DESA PENYANGGA DALAM KONSERVASI TAMAN NASIONAL ALAS PURWO BERBASIS KEARIFAN LOKAL
}

\author{
Eko Setiawan; Keppi Sukesi; Kliwon Hidayat; Yayuk Yuliati \\ Program Studi Sosiologi Fakultas Pertanian, Universitas Brawijaya \\ Email: oke.setia@gmail.com
}

\begin{abstract}
Abstrak
Penelitian ini menggambarkan kehidupan masyarakat sekitar kawasan desa penyangga Taman Nasional Alas Purwo, khususnya Dusun Kutorejo Desa Kalipait yang memiliki kearifan lokal berupa sejumlah tradisi, berupa aturan atau pantangan yang masih berlaku secara turun temurun. Kearifan lokal ini memiliki nilai kecerdasan ekologis yang dipelihara dan dikembangkan dan dipelajarinya tentang hubungan aktivitas manusia dengan ekosistemnya. Kearifan lokal yang dimiliki oleh masyarakat digunakan sebagai acuan dalam pengelolaan kawasan hutan dan perairan pantai, baik berupa mitos maupun pantangan. Pusat perhatian dari kajian ekologi menurut Julian Steward adalah proses adaptasi kultural terhadap lingkungan. Proses ini dipandang sebagai suatu bentuk hubungan dialektika dalam konteks hubungan saling ketergantungan dengan yang lain. Jenis penelitian yang digunakan adalah deskriptif kualitatif dengan desain studi kasus. Hasil penelitian menunjukkan masyarakat sekitar kawasan Taman Nasional Alas Purwo memiliki kearifan lokal berupa sejumlah tradisi, aturan atau pantangan yang masih berlaku secara turun temurun yang kemudian dipelihara dan ditaati sampai sekarang. Pantangan tersebut berupa larangan membunuh burung merak serta pantangan dalam sistem payang.
\end{abstract}

Kata Kunci: Konservasi, Taman Nasional Alas Purwo, Kearifan Lokal.

\section{Abstract}

This research describes the life of the community around the buffer village area of Alas Purwo National Park, especially Kutorejo Village Kalipait hamlet which has local wisdom in the form of a number of traditions, in the form of rules or restrictions that are still valid for generations. This local wisdom has the value of ecological intelligence that is maintained and developed and studied about the relationship of human activities with their ecosystems. Local wisdom owned by the community is used as a reference in the management of forest areas and coastal waters, both in the form of myths and abstinence. The center of attention from ecological studies according to Julian Steward is the process of cultural adaptation to the environment. This process is seen as a form of dialectical relationship in the context of interdependent relationships with others. The type of research used is descriptive qualitative with case study design. The results showed that the community around Alas Purwo National Park area has local wisdom in the form of a number of traditions, rules or restrictions that are still valid for generations that are then maintained and obeyed until now. The restrictions are in the form of a ban on killing peacocks and abstinence in the payang system.

Keywords: Conservation, Alas Purwo National Park, Local Wisdom.

Peran Masyarakat Sekitar Desa Penyangga dalam Konservasi Taman Nasional Alas 


\section{Pendahuluan}

Indonesia masih menempati peringkat kedua dunia dalam hal kekayaan biodiversitas, setelah Brazil. Indonesia memiliki 300.000 jenis spesies satwa atau $17 \%$ satwa di dunia (Warsito, 2010). Kekayaan jenis satwa yang dimiliki Indonesia antara lain 515 spesies mamalia, 1.539 spesies burung, $45 \%$ dari jumlah spesies ikan, 16\% spesies reptil, $15 \%$ spesies serangga yang ada di dunia juga terdapat di Indonesia (Mangi, 2013). Hutan tropis di Indonesia merupakan yang terluas kedua di dunia setelah Brazil (Istiawati, 2016). Indonesia adalah salah satu negara Megacenter of biodiversity (Astirin, 2000, Baliton et al., 2017). Kelimpahan jumlah yang melimpah dari tumbuhan dan satwa liar di Indonesia, menempatkan Indonesia sebagai negara dengan tingkat keanekaragaman tertinggi ke tiga di dunia (Dirjen KSDAE, 2016). Pemerintah Indonesia telah menetapkan kawasan konservasi sebanyak 521 unit, dengan luas 27.1 juta hektar untuk melindungi kekayaan keanekaragaman hayati (Ditjen PHKA, 2014). Salah satunya, hutan merupakan kekayaan alam yang wajib dijaga kelestariannya sebagai penyeimbang alam dan paruparu bumi. Ekosistem hutan terdapat bermacam keanekaragaman hayati dan non hayati. Hutan merupakan kawasan yang sangat potensial dalam kehidupan sosial ekonomi masyarakat yang hidup di sekitar hutan. Masyarakat yang tinggal sekitar hutan atau yang disebut masyarakat tradisional tidak dapat dipisahkan karena merupakan bagian dari ekosistem hutan.

Desa Kalipait adalah potret paling jelas bagaimana keunikan kemampuan beradaptasi struktur sosial masyarakat. Kehidupan masyarakatnya yang berada pada lahan magersari, dan memiliki posisi kunci dalam pengelolaan hutan. Sedangkan Dusun Kutorejo adalah sebuah dusun yang berbatasan langsung dengan wilayah Taman Nasional Alas Purwo, sehingga aktivitas berbagai kegiatan dan sangat bergantung dengan taman nasional sangat tinggi. Setiap hari mereka harus keluar masuk hutan Taman Nasional Alas Purwo, untuk mencari hasil hutan maupun biota laut. Mayoritas mata pencahariannya tergantung pada hutan, yakni sebagai pencari kayu dan sebagai nelayan. Hutan tidak hanya menjadi sumber pemenuhan kebutuhan hidup semata, namun memiliki fungsi sosial, budaya dan religiusitas. Hutan dan masyarakat sekitar kawasan taman

Peran Masyarakat Sekitar Desa Penyangga dalam Konservasi Taman Nasional Alas 
Dimensia: Jurnal Kajian Sosiologi | Vol 13 No 1| pISSN: 1978-192X elSSN: 2654-9344

nasional terdapat ikatan sangat erat yang

telah berlangsung sejak ratusan tahun

Penerapan Metode Pembelajaran Group Investigation (Gi) untuk Meningkatkan Kompetensi Investigasi Kelompok pada Siswa Kelas XI IPS 1 SMA Negeri 11 Yogyakarta 
silam. Masyarakat sekitar taman nasional memiliki nilai-nilai kearifan lokal yang terbentuk dari interaksi berulang-ulang antara masyarakat dengan sumberdaya alam hutan. Akibatnya terbangun suatu sistem tatanan sosial budaya masyarakat yang menyatu dengan ekosistem hutan. Hutan menjadi satu kesatuan lingkungan budaya menjadi tumpuan hidup masyarakat sekitar kawasan taman nasional untuk menopang sistem kehidupannya.

Berbagai kegiatan orang-orang di area hutan saat itu terus mendekati zona inti, ditempat tersebut mereka biasa mendirikan pemukiman sementara sebagai tempat peristirahatan untuk mencari hasil hutan maupun biota laut. Sebenarnya tantangan dalam perlindungan dan pengelolaan hutan di Indonesia seringkali datang dari masyarakat yang tinggal di sekitar hutan. Magdalena (2013) menyatakan, kelestarian pengelolaan hutan sangat tergantung kepada partisipasi masyarakat lokal dalam pengelolaan. Hubungan hutan dan masyarakat setempat tidak lepas dari konsep ekosistem yaitu suatu sistem ekologi yang terbentuk oleh hubungan timbal balik antara makhluk hidup dengan lingkungannya (Soemarwoto, 2014).
Gauthama, et al (2013) menyebutkan bahwa masyarakat Jawa mengimplementasikan hakekat hubungan manusia dengan alam dengan filsafah memayu hayuning bawana (mengusahakan keselamatan dunia beserta segala isinya agar tetap terpelihara dan harmonis). Persepsi masyarakat inilah yang dapat dijadikan penuntun moral dan pranata sosial dalam mengatur hubungan manusia dengan pemanfaatan sumberdaya alam hutan secara bertanggungjawab dan berkelanjutan.

Sebenarnya interaksi masyarakat terhadap hutan dengan kearifan lokalnya sudah berlangsung lama sebelum penetapan kawasan hutan menjadi kawasan konservasi. Kearifan lokal yang dapat mendukung konservasi terbentuk dari hasil interaksi antara manusia dengan lingkungannya sehingga masyarakat tradisional memiliki pemahaman yang lebih mendalam terhadap lingkungannya (Beltran \& Phillips, 2010). Kearifan lokal menunjukkan adanya hubungan yang tidak dapat dipisahkan antara perilaku manusia yang khas dengan lingkungannya yaitu membentuk perilaku manusia secara kolektif dalam bentuk norma-norma yang harus ditaati secara

Peran Masyarakat Sekitar Desa Penyangga dalam Konservasi Taman Nasional Alas 
turun temurun. Kearifan lokal dapat diterjemahkan sebagai akal budi, tabiat, perasaan mendalam dan anjuran untuk kemuliaan manusia. Penguasaan atas kearifan lokal akan mengusung jiwa mereka yang berbudi luhur (Yuliati, 2013). Senada dengan ungkapan Liliweri (2014), bahwa kearifan lokal dapat diartikan sebagai pandangan hidup yang berkembang dalam suatu komunitas sosial dan etnik tertentu yang dibatasi oleh unsur kedaerahan, letak geografis dan pengalaman sejarah yang unik.

Upaya kajian keterkaitan interaksi masyarakat sebenarnya telah dilakukan, namun masih belum memberikan hasil komprehensif. Van Assendelf (1991) telah melakukan penelitian tentang dampak manusia terhadap kawasan Taman Nasional Alas Purwo, namun penelitian ini hanya mendeskripsikan berbagai aktivitas manusia di sepanjang garis pantai, tidak secara spesifik mengidentifikasi pengaruh aktivitas manusia. Kajian yang lebih mengerucut pada interaksi manusia dengan kawasan taman nasional sebenarnya pernah dilakukan oleh Pramusanti (2001) tapi hanya sebatas berinteraksi dengan masyarakat dalam pemungutan sumberdaya alam. Febriyanti (2007) dalam penelitiannya bertujuan untuk mengetahui kondisi hutan mangrove dan kontribusinya terhadap pendapatan rumah tangga masyarakat dari nilai ekonomi bagi masyarakat sekitar kawasan Taman Nasional Alas Purwo. Satyasari (2010) kegiatan ekowisata mangrove di Taman Nasional Alas Purwo memberikan keuntungan ekonomi bagi masyarakat lokal, oleh karena itu pengembangan ekowisata mangrove di Bedul cenderung memenuhi prinsip keuntungan bagi masyarakat lokal. Azmi (2015) dalam penelitiannya, menilai penggunaan dan nilai spesies bagi masyarakat Desa Kalipahit di sekitar Taman Nasional Alas Purwo. Spesies memiliki peran dan nilai simbolik untuk stabilitas kelompok budaya dari waktu ke waktu didefinisikan sebagai spesies kunci budaya. Fiddarain (2016) kajian penelitiannya hanya di kawasan blok Patuk sebagai strategi problem solving yang bersifat solusi integratif demi terwujudnya kesepakatan bersama untuk meningkatkan kepedulian terhadap pelestarian kawasan Taman Nasional Alas Purwo. Beberapa kasus kegagalan dalam konservasi di atas seperti yang di sampaikan oleh Iswandono (2016) dalam penelitian ini belum adanya titik temu dalam pengelolaan bersama antara 
pengelola kawasan hutan dan masyarakat tradisional dalam melakukan konservasi hutan oleh karena itu pengelolaan hutan seharusnya mengintegrasikan kearifan lokal dengan prinsip-prinsip konservasi. Kearifan lokal yang mendukung konservasi keanekaragaman hayati memiliki tujuan yang sama, yaitu terwujudnya kelestarian keanekaragaman hayati untuk kesejahteraan masyarakat, tetapi pengetahuan tradisional kurang dipahami karena dianggap kuno dan tidak masuk akal (Kosmaryandi, 2012).

Urgensi pengkajian partisipasi dalam kegiatan partisipasi dalam kegiatan konservasi yang bersifat top down terbukti memberikan hasil tidak maksimal. Mendez-Lopez (2014) melakukan riset di Mexico juga mengakui bahwa rendahnya partisipasi masyarakat dalam kegiatan konservasi disebabkan banyaknya kondisi masyarakat yang belum lengkap ditelisik. Senada temuan Thaman (2016) membuktikan partisipasi masyarakat pedesaan dalam kegiatan konservasi di Portugal hanya $43 \%$, menjadikan konservasi tidak efektif. Berbeda di Fiji yang menggunakan pendekatan buttom up menunjukkan keterlibatan masyarakat yang besar $88 \%$ sehingga menjadikan kegiatan konservasi efektif. Pengaruh partisipasi masyarakat terhadap keberhasilan konservasi juga dapat dilihat di Costa Rica, ketika masyarakat berpartisipasi maka sektor swasta ikut terlibat (Aguilar-Stoen, 2015). Kondisi ini memberikan makna kegiatan yang menggunakan pendekatan partisipatif dan kebersamaan akan memberikan hasil yang baik.

Dari uraian tersebut di atas terlihat bahwa dengan heterogenitas masyarakat yang ada menyebabkan munculnya variasi perilaku sosial dan budaya di masyarakat terhadap lingkungan. Dengan adanya keunikan, keragaman budaya, hubungan lingkungan dan masyarakat tradisional di kawasan Taman Nasional Alas Purwo, menjadikan keunikan dan daya tarik untuk diteliti sesuai dengan permasalahan dimasa modern ini, seperti yang sudah dilakukan oleh penelitipeneliti sebelumnya yang masih berhubungan manusia dan lingkungannya. Novelty penelitian ini adalah menemukan suatu cara untuk melakukan konservasi keanekaragaman hayati dengan mengintegrasikan kearifan lokal masyarakat sekitar kawasan Taman Nasional Alas Purwo. Pentingnya pemahaman kearifan lokal pernah diungkapkan oleh Ihsannudin (2015b) 
bahwa kearifan lokal dalam konservasi sumberdaya alam yang dimiliki, sebagaimana nyampa di masyarakat Masalembu ternyata mampu menumbuhkan partisipasi masyarakat dalam melakukan konservasi sumberdaya alam. Tidak dapat dilupakan modal sosial harus dioptimalkan dalam pengelolaan sumberdaya alam agar optimal (Ihsannudin, 2015a). Sebagai jawabannya, Liberati (2016) mengusulkan adanya partnership berupa partisipasi ragam pemangku kepentingan.

Sudah banyak penelitianpenelitian yang mengintegrasikan kearifan lokal dan konservasi dengan fokus penelitian yang berbeda, diantaranya: fokus pada zonasi (Freitas \& Tagliani 2009, Kosmaryandi, 2012), sedangkan perbedaan, metode dan proses integrasi taman nasional (Bohensky \& Maru, 2011), pengetahuan tradisional ekologi mengenai populasi spesies (Fraser et al. 2006; Gagnon \& Berteaux 2009; Moller et al, 2004). Klasifikasi vegetasi dan lingkungan (Naidoo \& Hill 2006). Penelitian ini diharapkan dapat memberikan manfaat bagi para pemangku kepentingan, serta dukungan pada pengelola taman nasional untuk melibatkan masyarakat tradisional sekitar desa penyangga dengan mengintegrasikan kearifan lokal ke dalam kegiatan konservasi.

\section{Metode}

Penelitian ini menggunakan paradigma konstruktivisme sebagai landasan filosofis untuk memahami realitas di masyarakat dengan pendekatan kualitatif yang dilakukan dengan desain studi kasus. Penelitian kualitatif lebih menekankan pada proses dan makna yang tidak diuji atau diukur secara ketat dari segi kuantitas ataupun frekuensi (Denzin\&Lincoln, 2000). Data yang digunakan merupakan data kualitatif yang tidak terdiri dari angka-angka, melainkan berupa gambaran dan data (Rahmad, 2010). Selain itu metode penelitian kualitatif didefinisikan sebagai proses untuk mendapatkan pemahaman yang lebih baik mengenai kompleksitas dalam interaksi manusia (Sarwono, 2006). Hakikat penelitian kualitatif adalah mengamati orang dalam lingkungan hidupnya serta berinteraksi dengan mereka, berusaha memahami mereka tentang dunia sekitarnya dengan tujuan mencoba memahami, menggali pandangan dan pengalaman mereka untuk mendapat informasi yang 
diperlukan (Iskandar, 2009). Tujuan dari penelitian deskriptif adalah untuk menggambarkan objek sesuai apa adanya (Sukardi, 2008). Agar memperoleh hasil yang maksimal, maka dipilih strategi dan teknik penelitian yang dianggap tepat dan dapat dipertanggungjawabkan. Informan ditetapkan dengan teknik purposive. Pengumpulan data dengan menggunakan observasi dan wawancara. Penelitian ini berfokus pada penggalian data interaksi masyarakat lokal di sekitar kawasan Taman Nasional Alas Purwo dan persepsi masyarakat serta faktor sosial, ekonomi, budaya yang melatarbelakanginya. Dengan begitu, harmonisasi komunikasi dan interaksi dapat dicapai dengan maksimal (Neuman, 2003). Analisis data menggunakan model interaktif, meliputi komponen-komponen, pengumpulan data, reduksi data, sajian data, penarikan kesimpulan.

\section{Hasil dan Pembahasan}

\section{Eksistensi Masyarakat Sekitar Desa Penyangga}

Desa Kalipait adalah sebuah desa di Kabupaten Banyuwangi yang berada di wilayah bagian ujung selatan, tepatnya kurang lebih $60 \mathrm{~km}$ dari Pusat Pemerintahan Kabupaten Banyuwangi ke arah Selatan jalur menuju ke Taman Nasional Alas Purwo. Desa Kalipait adalah potret paling jelas bagaimana keunikan kemampuan beradaptasi struktur sosial masyarakat. Kehidupan masyarakatnya tinggal di desa penyangga memiliki posisi kunci dalam pengelolaan hutan. Sedangkan Dusun Kutorejo berbatasan langsung dengan wilayah Taman Nasional Alas Purwo, sehingga berbagai kegiatan dengan taman nasional sangat tinggi. Setiap hari mereka harus keluar masuk hutan, untuk mencari hasil hutan maupun biota laut. Interaksi antara masyarakat sekitar desa penyangga dan Taman Nasional Alas Purwo intens karena ketergantungan masyarakat pada sumberdaya alam masih tinggi. Tingkat ekonomi warga di daerah penyangga masih tergolong rendah, dan banyak yang bergantung pada pemanfaatan sumberdaya alam. Bentuk interaksi masyarakat sekitar desa penyangga dengan Taman Nasional Alas Purwo adalah pemungutan hasil hutan, pantai, yang ada di dalam kawasan taman nasional, yang dikenal dengan sebutan kayal.

Pengelolaan kawasan Taman 
Nasional Alas Purwo di Kabupaten Banyuwangi dinilai masih kurang efektif. Hal ini dikarenakan pengelolaan yang dilakukan belum mencapai tujuan yang ditetapkan. Selain itu luasnya kawasan hutan dan banyaknya permasalahan gangguan terhadap kawasan hutan itu sendiri. Undang-Undang No. 5 tahun 1990 tentang Konservasi Sumberdaya Alam Hayati dan Ekosistemnya mengamanatkan betapa pentingnya upaya perlindungan keanekaragaman hayati, termasuk satwa liar yang ada dalam kawasan. Sepertinya UndangUndang tersebut belum diimplementasikan secara optimal, masih banyaknya pelanggaran seperti perburuan satwa yang dilindungi, khususnya satu satwa liar yang terancam populasinya karena perburuan liar adalah banteng (Bos javanicus d'Alton), dan burung cucak hijau. Ancaman terhadap keberadaan dan populasi banteng dan burung cucak hijau sudah sejak lama. Situasi dan kondisi taman nasional yang berbatasan langsung dengan pemukiman penduduk lokal, khususnya Dusun Kutorejo menjadikannya rentan konflik penduduk dengan satwa. Salah satu pemicu konflik yaitu adanya satwa liar yang keluar kawasan dan mengganggu lahan masyarakat sekitar (Alikodra, 2012).

Selain itu permasalahan dalam kegiatan pemungutan yang dilakukan masyarakat, selama ini adalah selain memberikan nilai ekonomis kepada masyarakat, kegiatan ini juga cenderung berakibat atas rusaknya sumberdaya alam. Masih belum diakuinya kegiatan masyarakat dalam kegiatan pengelolaan taman nasional, sehingga tidak ada suatu peraturan atau kebijaksanaan yang mengakomodir masalah ini. Sehingga pada akhirnya yang menjadi korban adalah sumberdaya alam taman nasional itu sendiri. Padahal baik pengelola maupun masyarakat lokal sekitar kawasan sama-sama memiliki kebutuhan akan terjaminnya kelestarian sumberdaya alam. Pengelola taman nasional memiliki aturan atau pengkategorian gangguan yang terdiri pertama adalah kategori tingkat pelanggaran tinggi yaitu semua bentuk kegiatan yang mengakibatkan kematian atau hilangnya suatu sumberdaya, seperti perburuan satwa burung, penebangan pohon, tindakan membakar hutan. Tindakan pengamanan yang diambil oleh pengelola Taman Nasional Alas Purwo adalah dengan menangkap pelaku beserta barang buktinya. Kedua, kategori gangguan 
dengan tingkat pelanggaran sedang meliputi kegiatan pemungutan bambu dan gebang. Ketiga, kategori gangguan dengan tingkat pelanggaran rendah meliputi pemungutan kayu bakar. Pengambilan kayu dan bambu dengan skala yang besar dapat menurunkan daya dukung lingkungan (Poerwanto, 2000). Salah satu cara untuk meminimalisir gangguan terhadap sumberdaya alam adalah dengan mengikutsertakan masyarakat dalam kegiatan pengelolaan taman nasional sebagai mitra. Karena dengan diakuinya kegiatan pemungutan masyarakat, berarti masyarakat merasakan langsung manfaat keberadaan taman nasional tersebut, dan sekaligus memiliki tanggung jawab untuk menjaga keberlanjutan dari pemanfaatan yang dilakukannya.

Masyarakat desa mayoritas mata pencahariannya tergantung pada hutan dan pantai, yakni sebagai pencari kayu dan nelayan. Bagi mereka hutan tidak hanya menjadi sumber pemenuhan kebutuhan hidup, namun memiliki fungsi sosial, budaya dan religiusitas. Karena hutan dengan masyarakat sekitar kawasan taman nasional terdapat ikatan sangat erat yang telah berlangsung sejak ratusan tahun yang lalu. Masyarakat sekitar taman nasional memiliki nilai-nilai kearifan lokal yang terbentuk dari interaksi berulang-ulang antara masyarakat dengan sumberdaya hutan. Akibatnya terbangun suatu sistem tatanan sosial budaya masyarakat yang menyatu dengan ekosistem hutan. Hutan menjadi satu kesatuan lingkungan budaya menjadi tumpuan hidup masyarakat sekitar kawasan taman nasional untuk menopang sistem kehidupannya. Pusat kajian dari teori ekologi budaya dari Julian $\mathrm{H}$ Steward adalah lingkungan dan budaya tidak bisa dilihat terpisah, tetapi merupakan hasil campuran (mixed product) yang berproses lewat dialektika. Dengan kata lain proses ekologi memiliki hukum timbal balik dan saling mempengaruhi karena budaya dan lingkungan bukanlah entitas yang masing-masing berdiri sendiri atau bukanlah barang jadi yang bersifat statis (Agusyanto, 2012). Dalam hal tersebut konsep adaptasi menjadi konsep sentral antara manusia dengan kebudayaannya dengan lingkungan alam fisik dimana manusia itu hidup dan berkembang. Secara sederhana, hubungan antara manusia dengan lingkungannya dapat dilihat pada gambar berikut ini: 


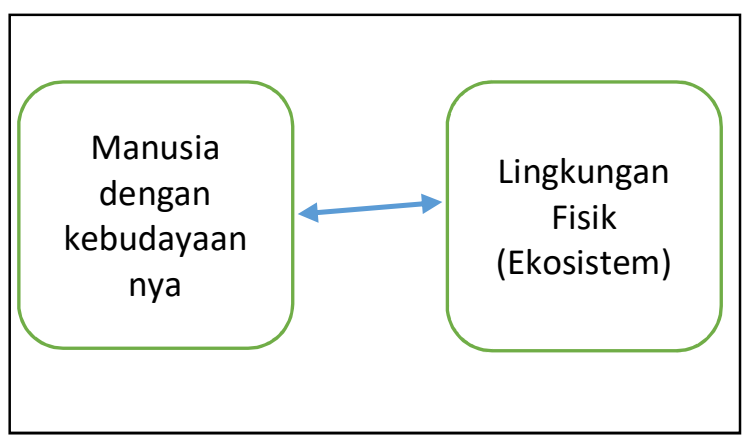

Masyarakat sekitar kawasan Taman Nasional Alas Purwo memiliki kearifan lokal berupa sejumlah tradisi yaitu aturan atau pantangan yang masih berlaku secara turun temurun dan ditaati masyarakat. Kearifan lokal memiliki nilai kecerdasan ekologis yang perlu dipelihara dan dikembangkan agar tidak tergilas oleh modernisasi. Kearifan lokal yang dimiliki oleh masyarakat digunakan sebagai acuan dalam pengelolaan kawasan hutan, berupa mitos dan praktik ritual keagamaan. Mereka menganggap bahwa hutan merupakan suatu pemberian dari Tuhan yang bersifat sakral. Mereka beranggapan bahwa anugerah tersebut harus dijaga kelestariannya agar tidak musnah, maupun dieksploitasi secara berlebihan. Selain itu mereka juga mempercayai bahwa hutan tersebut memiliki kekuatan magis, dan didukung adanya mitos-mitos yang diwariskan sejak zaman nenek moyang. Masyarakat sekitar melalui konsep mitos, praktik ritual, pengelolaan kawasan hutan. Mereka berusaha untuk selalu menjaga hubungan antara lingkungan alamnya agar tetap harmonis. Masyarakat lokal pada umumnya sangat mengenal dengan baik lingkungan sekitarnya. Mereka hidup dalam berbagai ekosistem alami dan telah lama hidup berdampingan dengan alam secara harmonis sehingga mengenal berbagai cara memanfaatkan sumberdaya alam secara berkelanjutan. Kearifan lokal yang dimiliki oleh masyarakat desa ini kemudian menimbulkan implikasi baik bagi lingkungan maupun bagi kehidupan masyarakat sekitar kawasan taman nasional. Kegiatan pengelolaan hutan di kawasan taman nasional, dengan adanya kearifan lokal tersebut berdampak positif akan pelestarian tumbuhan untuk menjaga keseimbangan ekosistem.

Masyarakat sekitar kawasan desa penyangga mempertahankan hutan sebagai bagian dari kehidupan mereka. Salah satunya ada beberapa cara yang dianggap tidak masuk akal seperti, tidak boleh mengambil kayu di hutan karena akan menyebabkan marahnya mahluk halus penunggu hutan, jika masuk hutan tidak boleh ribut jika tidak ingin terkena 
musibah, pantangan mengambil daun atau ranting jika tidak ingin diikuti oleh mahluk ghaib sampai ke rumah. Perlindungan hutan seperti itu, merupakan salah satu wujud perlindungan yang sangat efektif, sehingga kelestarian hutan tetap terjaga. Hutan dianggap sebagai titipan dari leluhur, melindungi hutan dengan cara tersendiri yang dilakukan oleh masyarakat lokal, merupakan suatu etika yang harus dilaksanakan dan sebagai bagian dari norma yang mereka miliki.

\section{Kearifan Lokal Masyarakat Desa}

\section{Penyangga dalam Konservasi}

Kelestarian kawasan hutan dan kehidupan masyarakat tradisional yang hidup di sekitarnya saling mempengaruhi dan tidak dapat dipisahkan. Hutan memiliki peranan penting yang bukan hanya sebagai penyeimbang iklim global tetapi juga sebagai sumber kehidupan masyarakat. Hutan menjadi media hubungan timbal balik antar manusia dan makhuk hidup lainnya dengan faktor alam dari proses ekologi yang mendukung keberlangsungan kehidupan. Dengan demikian kehidupan manusia pada dasarnya berhubungan erat dengan lingkungan alam karena bergantung pada ekosistem yang menjamin keberlangsungan hidupnya. Dengan kata lain, kelestarian kawasan hutan sangat dipengaruhi oleh pola kehidupan masyarakat tradisional karena mereka sangat bergantung pada sumberdaya alam hayati dan kondisi lingkungan di kawasan Taman Nasional Alas Purwo. Mereka berusaha memahami, mengenali, agar mampu memanfaatkan guna memenuhi kebutuhan mereka. Pengetahuan tersebut sangat penting bagi masyarakat sekitar kawasan, keterlibatan aktif masyarakat untuk mengelola hutan. Kearifan lokal merupakan kearifan lingkungan dalam bentuk tata nilai dan perilaku hidup dalam bermasyarakat di suatu tempat, baik antar sesama masyarakat maupun dalam berinteraksi dengan lingkungan mereka. Kearifan lokal merupakan bentuk pengetahuan, keyakinan, wawasan, pemahaman serta adat kebiasaan yang menuntun perilaku manusia dalam kehidupan manusia dalam kehidupan ekologis. Semua bentuk kearifan lokal ini dihayati, dipratekkan, diajarkan, diwariskan dari generasi ke generasi sekaligus membentuk pola perilaku manusia terhadap sesama manusia dan alam. Perilaku ini berkembang menjadi suatu kebudayaan di suatu daerah dan 
akan berkembang secara turun temurun, yang unsur-unsurnya adalah budaya suku bangsa yang tinggal di daerah itu (Aminudin, 2013). Nilai kearifan lokal dapat dihayati, dipratekkan, diajarkan dan diwariskan dari satu generasi ke generasi lainnya yang sekaligus membentuk pola perilaku manusia sehari-hari, baik terhadap alam maupun sesama manusia.

Kearifan lokal sering berkaitan dengan kearifan ekologi yang menjadi pedoman manusia dalam berinteraksi dengan lingkungan alam, biofisik dan supranatural yang memandang manusia merupakan bagian dari alam. Kearifan lokal terbentuk karena adanya hubungan antara masyarakat tradisional yang memiliki kepercayaan, hukum, pranata, ilmu pengetahuan dan cara mengelola sumberdaya alam secara lokal. Kearifan lokal merupakan hal utama bagi masyarakat dalam beradaptasi dengan alam dan menjadi suatu warisan budaya yang terkandung dalam konsep berfikir masyarakat setempat (Nurdin \& Ng, 2013). Kearifan lokal terbentuk sebagai keunggulan budaya masyarakat setempat maupun kondisi geografis dalam arti luas (Ayatrohaedi, 2016). Kearifan lokal (local wisdom) terdiri dari dua kata yaitu kearifan (wisdom) sedangkan lokal (local) menunjukkan ruang interaksi dimana peristiwa atau situasi tersebut terjadi (Wikantoyoso, 2019). Kearifan lokal sampai saat ini masih dipegang teguh oleh masyarakat tradisional sekitar kawasan taman nasional yang hidupnya bergantung pada alam terutama hutan dan laut. Hutan merupakan salah satu kekayaan alam yang wajib dijaga kelestariannya, di dalamnya terdapat bermacam-macam keanekaragaman hayati dan non hayati, baik flora maupun fauna. Hutan sebagai penyeimbang alam dan paru-paru bumi, merupakan kawasan yang sangat potensial terutama untuk kehidupan sosial ekonomi masyarakat yang hidup di sekitar hutan. Hutan menjadi sumber pemenuhan kehidupan sehari-hari oleh masyarakat. Masyarakat lokal merupakan kelompok masyarakat yang memiliki asal usul para leluhur secara turun temurun di wilayah geografis tertentu serta memiliki nilai, budaya, sosial, ideologi, ekonomi dan politik. Hal ini sangat berpengaruh pada pengelolaan hutan secara arif dan bijaksana oleh masyarakat tradisional sehingga pelestarian hutan dapat terjamin.

Masyarakat lokal sekitar desa penyangga pada umumnya sangat mengenal dengan baik lingkungan 
sekitarnya, mereka hidup dalam berbagai ekosistem alami dan telah lama hidup berdampingan dengan alam secara harmonis. Dengan kearifan lokal yang dimiliki sehingga mengenal berbagai cara memanfaatkan sumberdaya alam secara berkelanjutan, keseimbangan ekosistem lingkungan hutan untuk sekian lama terjaga dan lestari. Perilaku masyarakat dalam kaitannya dengan pemeliharaan lingkungan berkaitan dengan persepsi mereka tentang lingkungan lingkungan sekitar. Sikap masyarakat dalam memperlakukan alam sekitarnya juga dipengaruhi pengalaman dan pengetahuan mereka tentang kearifan lokal. Masyarakat yang tinggal di sekitar hutan yang mayoritas bermata pencaharian sebagai petani mempunyai hubungan yang sangat erat dengan lingkungannya. Disamping itu masyarakat mengenal sikap dan pola pikir serta dalam bertindak masih berpegang teguh pada norma, adat, serta tradisi yang diwarisi secara turun temurun. Dengan demikian kearifan lokal merupakan pandangan hidup dan pengetahuan tradisional yang menjadi acuan dalam berperilaku dan telah dipraktekan secara turun temurun untuk memenuhi kebutuhan dan tantangan dalam kehidupan.
Masyarakat sekitar kawasan Taman Nasional Alas Purwo memiliki kearifan lokal berupa sejumlah tradisi, aturan atau pantangan yang masih berlaku secara turun temurun yang kemudian dipelihara dan ditaati masyarakat. Kearifan lokal ini memiliki nilai kecerdasan ekologis yang perlu dipelihara dan dikembangkan agar tidak tergilas oleh modernisasi. Pengetahuan ekologi tradisional serta informasi studi ilmiah tidak hanya sekedar dibandingkan tetapi untuk diintegrasikan dalam pengelolaan sumberdaya alam (Brook\&McLachlan 2005). Dapat dibuktikan bahwa pengetahuan ekologi tradisional secara sains merupakan pengelolaan sumberdaya alam berdasarkan pada praktek pengelolaan tradisional. Untuk itulah penelitian ini bertujuan untuk mengintegrasikan kearifan lokal ke dalam konservasi yang mempertimbangkan keberadaan masyarakat setempat. Kearifan lokal yang dimiliki oleh masyarakat digunakan sebagai acuan dalam pengelolaan kawasan hutan, mitos, praktek ritual keagamaan. Mereka menganggap bahwa hutan merupakan suatu anugerah Tuhan atau pemberian dari Tuhan yang bersifat suci dan sakral. Mereka beranggapan 
bahwa anugerah tersebut harus dijaga keberadaannya agar tidak musnah, maupun dieksploitasi secara berlebihan. Selain itu mereka juga mempercayai bahwa hutan tersebut memiliki kekuatan magis, dan didukung adanya mitos-mitos yang diwariskan sejak zaman nenek moyang. Masyarakat sekitar melalui konsep mitos, praktik ritual, pengelolaan kawasan hutan, mereka berusaha untuk selalu menjaga hubungan antara lingkungan alamnya agar tetap harmonis. Masyarakat lokal pada umumnya sangat mengenal dengan baik lingkungan sekitarnya. Mereka hidup dalam berbagai ekosistem alami, dan telah lama hidup berdampingan dengan alam secara harmonis sehingga mengenal berbagai cara memanfaatkan sumberdaya alam secara berkelanjutan. Kearifan lokal yang dimiliki oleh masyarakat desa ini kemudian menimbulkan implikasi baik bagi lingkungan maupun bagi kehidupan masyarakat sekitar kawasan taman nasional. Kegiatan pengelolaan hutan di kawasan taman nasional dengan adanya kearifan lokal tersebut berdampak positif akan pelestarian tumbuhan untuk menjaga keseimbangan ekosistem.

\section{Larangan Mengambil atau Membunuh Burung Merak \\ Sebenarnya masyarakat} tradisonal yang ada di sekitar kawasan Taman Nasional Alas Purwo, memiliki cara-cara di dalam upaya konservasi. Kearifan lokal yang dimiliki oleh masyarakat sekitar kawasan taman nasional, ternyata memiliki nilai konservasi yang cukup tinggi dalam menjaga kelestarian alam yang saat ini masih dipakai dalam kehidupan seharihari. Kearifan lokal di dalam memanfaatkan sumber daya alam, hingga saat ini masih dilakukan dan diyakini secara turun temurun dari generasi ke generasi. Maksud dan tujuannya berupa lambang-lambang atau pertanda dapat berbentuk larangan, seperti pantangan mengambil atau membunuh burung merak. Larangan mengambil maupun membunuh burung merak, menurut masyarakat karena disebabkan karena burung merak merupakan binatang kesayangan para makhluk halus penungggu Taman Nasional Alas Purwo. Burung merak merupakan hewan di lindungi dan unik lantaran memiliki warna keemasan, panjangnya bisa mencapai $300 \mathrm{~cm}$, dengan penutup ekor yang panjang, dan terdapat jambul tegak di 
atas kepalanya. Terdapat perbedaan yang mencolok untuk merak betina karena berukuran lebih kecil, warna bulunya kurang mengkilap, berwarna keabu-abuan, tanpa hiasan bulu penutup ekor. Burung merak memiliki nilai ekonomi tinggi dan dapat dimanfaatkan dalam bentuk hidup (sebagai satwa pelihara untuk kepentingan ekowisata).

Sampai saat ini masih ditaati oleh masyarakat di sekitar kawasan taman nasional, karena nilai-nilai konservasi yang ada masyarakat secara tidak langsung melakukan upaya pengawetan keanekaragaman hayati. Khususnya satwa burung merak merupakan salah satu komponen dari ekosistem, sehingga dengan terjaganya satwa tersebut mutu dan kualitas ekosistem secara tidak langsung dapat dijaga. Selain itu masyarakat sekitar kawasan taman nasional juga mengembangkan sebentuk adaptasi hidup bersama satwa. Bentuk kearifan lokal terlihat dari panggilan hormat kepada satwa gajah dan harimau dengan sebutan simbah. Gajah dipanggil dengan sebutan simbah gede, harimau dengan sebutan simbah loreng. Menyebut atau mengucap kata harimau dipercayai hanya mencari perkara, harimau punya telingan bumi, bila menyebut harimau maka kata ini merambat di dalam tanah, ia mendengar lalu akan datang.

Dalam pembahasan di atas dapat diketahui bahwa satwa endemik yaitu burung merak keberadaannya semakin langka dan terancam punah. Burung memiliki peran dalam berbagai aspek kehidupan, baik ekologi maupun ekonomi dan sosial. Semakin maraknya perburuan terhadap keberadaan satwa tersebut karena bernilai ekonomis tinggi, merupakan suatu alasan kuat melakukan pengawasan lebih lanjut. Salah satunya upaya konservasi merupakan alternatif untuk memberikan perlindungan terhadap satwa. Salah satu program yang dilakukan oleh pihak Balai Taman Nasional Alas Purwo dengan melibatkan masyarakat sekitar yaitu melakukan penangkaran terhadap burung merak. Tujuan dari kegiatan tersebut tidak hanya melakukan perlindungan tetapi lebih pada peningkatan produktivitas burung yang mulai terancam. Pengembangbiakan burung tentunya untuk menambah populasi agar terhindar dari kepunahan. Kegiatan konservasi burung seyogyanya tidak hanya dilakukan oleh Lembaga Pemerintah saja dengan melibatkan 
semua komponen masyarakat. Perlu adanya koordinasi yang intensif antara lembaga formal dan non formal, sehingga ada sinkronisasi yang lebih terarah dalam menjalankan berbagai kegiatan konservasi terhadap burung.

\section{Pantangan dalam Sistem Payang}

Sistem payang termasuk alat penangkap ikan atau udang yang sudah lama dikenal nelayan Indonesia. Payang salah satu alat penangkap ikan tradisional yang masih ditemukan di lapangan walaupun jumlahnya semakin kecil. Payang merupakan alat penangkapan ikan yang sudah lama dikenal dan digunakan oleh nelayan Indonesia hingga saat ini. Payang dapat dikategorikan sebagai alat yang memiliki produktivitas tinggi dan dapat digolongkan sebagai alat penangkap ikan yang masih bersifat tradisional (Palo\&Assir, 2019). Payang merupakan pukat kantong yang digunakan untuk menangkap gerombolan ikan permukaan (Brandt, 1995). Payang biasanya digunakan untuk menangkap jenis-jenis ikan permukaan (pelagic fish), dimana pada dasarnya kontruksi alat tangkap ini menpunyai bagian-bagian yang terdiri dari jaring (kantong, badan dan sayap), pelampung, pemberat, tali.
Jaring merupakan komponen utama pada payang dan sebagian besar bahan dari kontruksi payang terdiri dari jaring. Secara umum kontruksi payang terdiri dari tiga bagian (sayap, badan dan kantong). Masing-masing bagian memiliki ukuran dan dimensi yang berbeda-beda antara satu payang dengan payang lainnya. Bagian kantong pada payang merupakan tempat untuk menampung ikan hasil tangkapan. Biasanya jaring pada kantong terbuat dari bahan polyamide. Badan jaring merupakan bagian jaring, biasanya terletak ditengahtengah jaring antara sayap dan kantong. Ukuran panjang badan jaring bervariasi antara $16-18 \mathrm{~m}$. Panjang jaring tergantung dari besarnya mata jaring yang digunakan dan jumlah banyaknya mata jaring.

Sayap merupakan bagian terpanjang antara 60-70m dari seluruh bagian payang yang terdiri dari sayap kanan maupun sayap kiri. Ukuran sayap yang panjang dimaksudkan agar dapat membatasi atau mencakup daerah perairan dengan seluas-luasnya sehingga dengan cepat dapat menghadang gerombolan ikan pelagis yang memiliki kecepatan renang yang tinggi, agar dapat menggiring ikan masuk kedalam kantong. 
Pelampung berfungsi untuk membantu bukaan mulut jaring, serta untuk mempertahankan bentuk jaring sesuai yang diinginkan. Pelampung yang digunakan pada payang, biasanya ada dua macam yaitu pelampung utama (caka atas) dan pelampung (kulu) pada sayap. Semua pelampung tidak dipasang secara permanen pada jaring, hanya dipasang pada saat pengoperasian jaring, setelah itu dilepas kembali. Hal ini dilakukan bertujuan untuk mempermudah penanganan jaring supaya volumenya tidak terlalu besar.

Pemberat berfungsi agar bagian bawah mulut jaring terendam dengan sempurna sehingga membentuk bukaan mulut jaring secara menganga maksimal. Pemberat berfungsi agar bagian bawah jaring terendam dengan baik sehingga membentuk bukaan mulut jaring yang maksimal (Boesono, 2014). Semua pemberat kecuali caka bawah tidak dipasang secara permanen. Pemasangan pemberat dilakukan pada saat pengoperasian jaring, kemudian setelah selesai hauling pemberat dilepas.

Tali-temali sangat mendukung dalam konstruksi payang, terdiri dari tali ris berfungsi untuk memperkuat jaring dan sekaligus tempat mengikat jaring. Pada payang biasanya terdiri tali ris atas dan tali ris bawah digunakan pada bagian sayap serta mulut jaring. Tali ris tidak diikat pada jaring, namun hanya dimasukan kedalam mata jaring yang terluar dari sayap atau bagian pinggir luar sayap. Kondisi ini menyebabkan pembukaan mata jaring menjadi tidak beraturan, pada saat dilakukan penarikan jaring, mata jaring cenderung tertutup sehingga memungkinkan ikan-ikan kecil tidak lolos melalui mata jaring.

Untuk menunjang operasional penangkapan ikan menggunakan payang, ada beberapa hal yang perlu diperhatikan, diantaranya pemeriksaan mesin pada perahu, penyediaan BBM, serta mengatur posisi alat tangkap. Payang biasanya dioperasikan di daerah permukaan, karena target tangkapannya ikan yang bergerombol. Pengoperasian payang di perairan berada pada kedalaman 250$350 \mathrm{~m}$ dengan kedalaman jaring berkisar 20-30m sehingga tidak berdampak pada kerusakan ekosistem laut. Proses penurunan jaring biasanya ditandai ketika nelayan sudah bersiap-siap untuk menurunkan rakit dari kapal dan memisahkan atraktor dengan sebuah pelampung besar tempat dimana kapal ditambatkan. Dimana 1 Anak Buah Kapal 
(ABK) akan turun ke rumpon untuk diikatkan pada sebuah tali panjang yang dipegang oleh seorang $A B K$ yang berada dikapal (punggawa) untuk mengulur dan menarik rumpon pada saat pengoperasian berlangsung.

Setelah penentuan arah untuk operasi penangkapan, kapal akan bergerak mengelilingi rumpon. Proses melingkari rumpon dilakukan berlawanan dengan arah jarum jam, dimana posisi alat tangkap berada pada buritan sebelah kiri kapal. Pada saat kapal sedang mengelilingi rumpon, maka hal pertama yang dilakukan adalah melempar pelampung bola yang sudah diikat pada tali pada salah satu bagian sayap. Selanjutnya penurunan tali selambar dilakukan, maka setelah tali selambar turun, selanjutnya penurunan bagian sayap jaring. Kemudian penurunan pelampung dan pemberat pada sayap, penurunan pelampung dan pemberat dilakukan secara bergantian, dimana penurunan pelampung terlebih dahulu dilanjutkan dengan pemberat, kemudian pelampung yang berbentuk bola yang terletak pada mulut jaring bagian atas serta pemberat. Setelah bagian sayap diturunkan, maka dilanjutkan dengan penurunan badan kantong dan bagian sayap disisi lain serta penurunan tali selambar.

Selanjutnya dalam proses penarikan jaring dilakukan setelah jaring payang melingkari rumpon dan kedua tali selambar bertemu, setelah tali selambar sudah berada di atas kapal maka akan dilkukan penarikan tali selambar. Proses penarikan jaring harus dilakukan dengan cepat, dengan harapan untuk menutup peluang ikan untuk meloloskan diri. Waktu yang dibutuhkan untuk penarikan jaring hingga semua bagian jaring naik kekapal sekitar 8-15 menit, mesin tetap dinyalakan dengan kecepatan rendah hingga hasil tangkapan pada jaring berada di atas kapal. Setelah kantong berada di atas kapal dan sudah aman dari resiko Iolosnya hasil tangkapan, maka tali pengikat pada ujung kantong dibuka dan hasil tangkapan ditempatkan pada sebuah box. Proses setting dan hauling yang dilakukan di daerah rumpon pada kedalaman sekitar $30 \mathrm{~m}$, letaknya sangat jauh dari dasar perairan, sehingga tidak mengganggu dasar perairan. Dari segi pengoperasian payang, tidak menunjukkan kondisi yang dapat merusak lingkungan maupun sumberdaya ikan.

$$
\text { Penangkapan }
$$

dengan menggunakan jaring payang dapat 
dilakukan baik pada malam maupun siang hari. Untuk malam hari, terutama pada hari-hari gelap atau tidak dalam keadaan terang bulan dengan menggunakan alat bantu berupa lampu petromaks. Sedang penangkapan yang dilakukan pada waktu siang hari menggunakan alat bantu rumpon atau hanya dengan cara menduga-duga di tempat yang dikira banyak ikan. Biasanya pada bulan april, mei, juni, para nelayan sering menggunakan alat tangkap payang dengan alat bantu lampu dan penangkapan dilakukan pada saat malam hari. Sedangkan jika sudah memasuki bulan september, oktober, para nelayan menggunakan alat bantu rumpon dan penangkapan dilakukan pada pagi hingga sore hari (Amry, Renta, \& Nofridiansyah, 2017). Rumpon yang ada sangat sederhana dan masih terbuat dengan cara tradisional. Bahan dari rumpon ini terdiri dari daun kelapa kering, ranting, ban bekas, tali tampar dan batu besar yang berfungsi sebagai pemberat. Rumpon merupakan wujud kearifan lokal yang memberikan pendidikan tentang pelestarian lingkungan, dimana memberikan tempat untuk menjadi rumah bagi ikan dan bukan sebaliknya merusak lingkungan. Bahkan jika kita lihat dan kaji lebih dalam lagi akan berdampak positif bagi lingkungan, yaitu dengan adanya rumpon ini maka sebagai rumah bagi ikan sebagai tempat berlindung dari predator, disamping itu terjadi rantai makanan sebagai wujud keseimbangan alam akan terjadi disekitar rumpon. Hal ini saja sebagai salah satu wujud kepedulian masyarakat nelayan terhadap lingkungan, dengan diterapkannya kearifan lokal rumpon ini, diharapkan masa mendatang dapat ditumbuh kembangkan dengan teknologi yang lebih baik, berupa pembangunan terumbu karang buatan.

Nelayan di Pantai Plengkung mengenal tiga musim penangkapan ikan, yaitu musim paceklik, sedang dan puncak. Pada musim paceklik hasil tangkapannya sangat rendah, waktu musim sedang hasil tangkapannya sedang, sedangkan waktu musim puncak hasil tangkapannya tinggi. Sistem pelaksanaan penangkapan ikan dengan menggunakan metode payang, dilakukan pada lima hari sebelum bulan purnama sampai lima hari setelah bulan purnama karena pada waktu itu terjadi air pasang sehingga mengakibatkan ikan dan udang terbawa arus hingga jatuh ke dalam muara. Sistem ini hanya bisa dilaksanakan pada sekitar bulan purnama, sedangkan pada hari yang lain 
tidak bisa dilakukan. Pelaksanaan sistem payang, terdapat beberapa pantangan untuk tidak boleh melakukan kegiatan lain seperti menjala. Berdasarkan kepercayaan jika melanggar pantangan maka hasil yang didapat di dalam payangan akan sedikit. Sesama pencari ikan yang memakai sistem payang akan menasehati temannya jika melanggar pantangan tersebut. Nilai-nilai konservasi yang terdapat dalam sistem payang, maka pemanfaatan sumberdaya alam dengan menggunakan peralatan sederhana dan ramah lingkungan mengakibatkan meminimalkan merusak ekosistem. Adanya beberapa pantangan selama melakukan payang dengan menggunakan alat lain untuk mengambil sumberdaya alam, di situ terdapat pendidikan moral bahwa pelaku payang diajak untuk bijaksana dalam mengambil sumberdaya alam seperlunya saja tidak berlebihan.

\section{Simpulan}

Taman Nasional Alas Purwo menjadi berpotensi sebagai penyangga kehidupan dikarenakan dalam pengelolaannya masih menerapkan kearifan lokal. Masyarakat sekitar kawasan Taman Nasional Alas Purwo memiliki kearifan lokal berupa sejumlah tradisi, aturan atau pantangan yang masih berlaku secara turun temurun yang kemudian dipelihara dan ditaati sampai saat ini. Kehidupan masyarakat sekitar desa penyangga sangat erat kaitannya dengan upaya konservasi. Hal ini dapat dilihat dari bentuk kearifan lokal, seperti:

(a) larangan mengambil atau membunuh burung merak. Pantangan tersebut menurut keyakinan masyarakat bahwa burung merak merupakan binatang kesayangan para makhluk halus penungggu Taman Nasional Alas Purwo. Saat ini masih ditaati oleh masyarakat sekitar kawasan taman nasional. Sebenarnya dengan adanya pantangan tersebut mereka telah menerapkan nilai-nilai konservasi yang ada masyarakat, secara tidak langsung merupakan upaya pengawetan keanekaragaman hayati. Khususnya satwa burung merak merupakan salah satu komponen dari ekosistem, sehingga dengan terjaganya satwa tersebut mutu dan kualitas ekosistem secara tidak langsung dapat dijaga keutuhannya.

(b) Sistem payang termasuk alat penangkap ikan atau udang yang 
sudah lama dikenal luas mayoritas nelayan Indonesia. Alat tangkap masih bersifat tradisional dan memiliki produktivitas tinggi. Berdasarkan kepercayaan jika melanggar pantangan maka hasil yang didapat di dalam payangan akan sedikit. Nilai-nilai konservasi yang terdapat dalam sistem payang, berupa pemanfaatan sumberdaya alam dengan menggunakan peralatan sederhana dan ramah lingkungan dapat meminimalkan merusak ekosistem laut.

\section{Ucapan Terima Kasih}

Terimakasih disampaikan kepada semua pihak yang terlibat dalam penelitian ini sehingga terlaksana dengan baik dan tim redaksi Jurnal Pendidikan Sosiologi Fakultas IImu Sosial UNY yang telah mempublikasikan penelitian ini.

\section{Daftar Pustaka}

Aguilar-Stoen, Mariel. (2015). Global forest conservations initiativies as spaces for participation in Colombia and Costa Rica. Journal Geoforum 61 (2015) 36-44.

Agusyanto. (2012). Jaringan Sosial. Jakarta: UI Press
Alikodra, H.S. (2012). Konservasi sumberdaya alam dan lingkungan. Pendekatan ecosophy bagi penyelamatan bumi. Yogyakarta: Gadjah Mada University Press.

Aminudin. (2013). Menjaga Lingkungan dengan Kearifan Lokal. Bandung: Titian IImu.

Amry, R. A., Renta, P. P., \& Nofridiansyah, E. (2017). Analisa Kelayakan Usaha Penangkapan Ikan Menggunakan Alat Tangkap Payang (Seine Net) Menggunakan Alat Bantu Rumpon Di Pantai Malabero Kota Bengkulu. Jurnal Enggano, 2(2), 129-142. https://doi.org/10.31186/jenggano.2 .2.129-142

Astirin. (2000). Permasalahan Pengelolaan Keanekaragaman Hayati di Indonesia. Jurnal Biodiversitas. 1(1): 36-40.

Ayatrohaedi. (2016). Kepribadian Budaya Bangsa. Jakarta: Pustaka Jaya.

Azmi, Rizka Syabana. (2015). Konservasi Spesies Kunci Budaya Masyarakat Desa Kalipahit di Sekitar Taman Nasional Alas Purwo, Jawa Timur. Skripsi. Bogor (ID): Institut Pertanian Bogor.

Baliton RS., Wulandari C., Landicho LD., Cabahug RED., Paelmo RF., Comia RA., Roberto G., Budiono P., Herwanti S., Rusita and Castillo AKSA. 2017. Ecological Services of Agroforestry Landscapes in Selected Watershed Area inThe Philippines and Indonesia. JOURNAL 
BIOTROPIA. 24(1): 71-84.

Beltrán J, Phillips A. (2010). Indigenous and traditional peoples and protected areas: principles, guidelines and case studies. Cambridge (UK): IUCN, Cambridge and WWF International.

Bohensky EL, Maru Y. (2011). Indigenous Knowledge, Science, and Resilience: What Have We Learned from a Decade of International Literature on Integration?. Ecology and Society. 16(4): $1-7$

Boesono, W. A. H. (2014). Analisis Efisiensi Teknis Genuine Payang Dan Modifikasi Payang Dengan Windows Samping Terhadap Hasil Tangkapan Di Perairan Kabupaten Kendal. Journal of Fisheries Resources Utilization Management and Technology, 3, 46-53.

Brandt, A.V. (1995. Classification of Fisher Gear, Modern Fishir Gear of The World. Fishing News. Ltd London.

Brook RK, McLachlan SM. (2005). On using expert-based science to "test" local ecological knowledge. Ecology and Society 10(2): 17-24

Denzin, NK and YS Lincoln (eds). (2000). Handbook of Qualitatif Research (Second Edition), Thousand Oaks, London, New Delhi: Sage Publication.

$\begin{array}{lrr}\text { Direktorat } & \text { Jenderal } & \text { Konservasi } \\ \text { Sumberdaya Alam dan } & \text { Ekosistem } \\ \text { (KSDAE). } & \text { (2016). } & \text { Statistik } \\ \text { Direktorat } & \text { Jenderal } & \text { KSDAE. } \\ \text { Jakarta: } & \text { KLHK. } & \end{array}$

Direktorat Jenderal Perlindungan Hutan dan Konservasi Alam (Ditjen PHKA). (2014). Statistik. Jakarta: Ditjend PHKA.

Febriyanti, Dwiyandhi. (2007). Studi Nilai Manfaat Hutan Mangrove Resort Bedul bagi Masyarakat Sekitar Kawasan Taman Nasional Alas Purwo, Banyuwangi. Skripsi. Bogor (ID): Institut Pertanian Bogor.

Fiddarain, Arrajih. (2016). Rancangan Solusi Konflik Lahan di Taman Nasional Alas Purwo. Skripsi. Bogor (ID): Institut Pertanian Bogor.

Fraser DJ, Coon T, Prince MR, Dion R, Bernatchez L. (2006). Integrating Traditional and Evolutionary Knowledge in Biodiversity Conservation: a Population Level Case Study. Journal Ecology and Society. 11(2):1-7.

Freitas DMD, Tagliani PRA. (2009). The Use of GIS for The Integration of Traditional and Scientific Knowledge in a Supporting Artisanal Fisheries Management in Southern Brazil. Journal of Enviromental Management. 90(6):2071-2078.

Gagnon CA, Berteaux D. (2009). Integrating Traditional Ecological Knowledge and Ecological Science: a Question of Scale. Journal Ecology and Society. 14(2):1-8.

Gauthama, M.P, Kusrestuwardhani, Alkadri. (2013). Budaya Jawa dan Masyarakat Modern. Jakarta: BPPT Press. 
Ihsannudin. (2015a). The Role of Social Capital on Salt Smallholder Society of Madura Indonesia in Land Certification Ownership. Scientific Journal of PPI-UK 2(4): 144-151.

Ihsannudin. (2015b). Fisherman's Behavior of Multi Ethnic Community In Adapting Climate Change In Small Island. International Journal of Andalas 2(2): 1-14

Iskandar. 2009. Metodologi Penelitian Kualitatif. Jakarta: Gaung Persada.

Istiawati, N. F. (2016). Pendidikan Karakter Berbasis Nilai-Nilai Kearifan Lokal Adat Ammatoa Dalam Menumbuhkan Karakter Konservasi. CENDEKIA: Journal of Education and Teaching, 10(1), 1.

https://doi.org/10.30957/cendekia. v10i1.78.

Iswandono, Elisa. (2016). Integrasi Kearifan Lokal Masyarakat Suku Manggarai dalam Konservasi Tumbuhan dan Ekosistem Pegunungan Ruteng Nusa Tenggara Timur (Disertasi). Bogor (ID): Institut Pertanian Bogor.

Kosmaryandi N. (2012). Pengembangan Zonasi Taman Nasional: Sintesis Kepentingan Konservasi Keanekaragaman hayati dan Kehidupan Masyarakat Adat [Disertasi]. Bogor (ID): Institut Pertanian Bogor.

Liberati. (2016). Beyond Protection: Expanding Concervation Opportunity to Redefine Conservation Planning in the 21st Century. Journal of Environmental Management. http://dx.doi.org/10.1016/j.jenvma n.2016.08.041.

Liliweri, A. (2014). Pengantar Studi

Kebudayaan. Bandung: Nusamedia.

Magdalena. (2013). Peran Hukum Adat Dalam Pengelolaan Dan Perlindungan Hutan Di Desa Sesaot, Nusa Tenggara Barat dan Desa Setulang, Kalimantan Timur. Jurnal Sosial Ekonomi. Vol.10 No.2.

doi.org/10.14710/jkt.v19i2.839.

Mangi, H. (2013). Asosiasi Burung Julang Sulawesi (Rhyticeros cassidix) dengan Pohon Eboni (Diospyros celebica Bakh) di Cagar Alam Pangi Binangga Desa Pangi Kabupaten Parigi Moutong. Jurnal Warta Rimba 1(1): 1-8.

Mendez-Lopez. (2014). Local participation in biodiversity conservation initiatives: a comparative analysis of different models in South East Mexico. Journal of Environmental Management 125(1): 321-329.

Moller H, Berkes F, Lyyer PO, Kislalioglu M. (2004). Combining Science and Traditional Ecological Knowledge: Monitoring Populations for CoManagement. Journal Ecology and Society. 9(3):1-10.

Naidoo R, Hill K. (2006). Emergence of Indigenous Vegetation Classifications Through Integration of Traditional Ecological Knowledge and Remote Sensing Analyses. Journal Enviromental Management. 38(3):377-386.

Neuman, William Lawrence. (2003). Social Research Methods: Qualitative and quantitative Approaches. Pearson Education. 
Nurdin, B. V., and Ng, K. S. F. (2013). Local Knowledge of Lampung People in Tulang Bawang: An Ethnoecological and Ethnotechnological Study for Utilization and Conservation of Rivers. Procedia - Social Science and Behavioral. 91: 113-119.

Palo, M., \& Assir, A. (2019). Analisis Aspek Teknis Jaring Payang Di Perairan Mamuju, Sulawesi Barat Analyses on Technical Aspects of Scottish Seine Net in. 6(12), 214229.

Poerwanto, Hari. (2000). Kebudayaan dan Lingkungan: Dalam Persepektif Antropologi. Yogyakarta: Pustaka Pelajar.

Pramusanti. (2001). Interaksi Masyarakat Sekitar dengan Taman Nasional Alas Purwo (Studi Kasus di Desa Kendalrejo Kecamatan Tegaldimo Kabupaten Banyuwangi Provinsi Jawa Timur) [Skripsi]. Bogor (ID): Institut Pertanian Bogor.

Rahmat, Jalaluddin. 2010. Metode

Penelitian Komunikasi. Bandung:

Remaja Rosdakarya.

Sarwono, J. 2006. Metode Penelitian Kuantitatif dan Kualitatif. Yogyakarta: Graha IImu.

Satyasari, Ika. (2010). Evaluasi Pengembangan Ekowisata Mangrove: Studi Kasus di Bedul, Resort Grajagan, Taman Nasional Alas Purwo, Jawa Timur. Skripsi. Bogor (ID): Institut Pertanian Bogor.

Soemarwoto, Otto. (2014). Ekologi, Lingkungan Hidup dan
Pembangunan. Djambatan.

Jakarta:

Sukardi. 2008. Metodologi Penelitian Pendidikan Kompetensi dan Praktiknya. Jakarta: Bumi Aksara.

Thaman. (2016). A comparison of rural comunity perceptions and involvement in conservations between the Fiji Island and Southwestern Portugal. Journal Ocean \& Coastal Management 133 (2016) 43-52.

Van Assendelf HB. (1991). Werholes, Mammals and Human Impact in Alas Purwo Baluran National Park East Java Indonesia, An Inventory along the coast in 1991. FONC project, Fakultas Kehutanan Universitas Gajah Mada, Yogyakarta.

Warsito. (2010). Penyebaran dan Populasi Burung Paruh Bengkok Pada Beberapa Tipe Habitat di Papua. Jurnal Penelitian Hutan dan Konservasi Alam 7(1): 93 102.

Wikantoyoso, Respati. (2019). Kearifan Lokal Dalam Perencanaan dan Perancangan Kota; Untuk Mewujudkan Arsitektur Kota Berkelanjutan. Malang: Malang Grup Konservasi Arsitektur dan Kota.

Yuliati, Yayuk. (2011). Perubahan Ekologis Dalam Strategi Adaptasi Masyarakat di Pegunungan Tengger (Suatu Kajian Gender dan Lingkungan). Malang: UB Press. 